\title{
Gaseous Emission from the Combustion of Premium Motor Spirit (PMS) from the Kaduna Refinery and Petrochemical Company (KRPC) in Nigeria
}

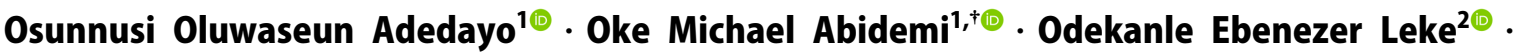 \\ Sonibare Jacob Ademola ${ }^{1 \oplus} \cdot$ Ige Oluwafunmiso Ayodele $^{1} \cdot$ Oyewale Babatunde Oyeleke $^{1}$. \\ Odewale Stephen Ayodele ${ }^{1}$
}

'Department of Chemical Engineering, Obafemi Awolowo University

${ }^{2}$ Department of Chemical Engineering, Technical University

(Received March 18, 2021; Revised April 16, 2021; Accepted April 28, 2021)

Objectives: This study characterizes the gaseous emission from the combustion of PMS of different volumes from Kaduna Refinery and Petrochemical Company.

Methods: The E8500 plus combustion analyzer was used for gaseous emission characterization of different volumes. Oxygen $\left(\mathrm{O}_{2}\right)$, Hydrocarbons $(\mathrm{HC})$, carbon monoxide $(\mathrm{CO})$, carbon dioxide $\left(\mathrm{CO}_{2}\right)$, Oxides of Nitrogen $\mathrm{NO}_{x}$ $\left(\mathrm{NO}, \mathrm{NO}_{2}\right)$, Sulphur dioxide $\left(\mathrm{SO}_{2}\right)$, and Hydrogen Sulfide $\left(\mathrm{H}_{2} \mathrm{~S}\right)$ were measured using the analyzer. The values were recorded and the descriptive statistics graph was plotted.

Results and Discussion: The concentrations for the gaseous emission from the combustion of PMS were 69.85 $\mathrm{mg} / \mathrm{m}^{3} \mathrm{HC}, 117.33 \mathrm{mg} / \mathrm{m}^{3} \mathrm{CO}, 334 \mathrm{mg} / \mathrm{m}^{3} \mathrm{NO}_{\mathrm{x}}$ for $10 \mathrm{ml}, 58.93 \mathrm{mg} / \mathrm{m}^{3} \mathrm{HC}, 130.33 \mathrm{mg} / \mathrm{m}^{3} \mathrm{CO}, 784.33 \mathrm{mg} / \mathrm{m}^{3}$ $\mathrm{NO}_{\mathrm{x}}$ for $20 \mathrm{ml}, 50.20 \mathrm{mg} / \mathrm{m}^{3} \mathrm{HC}, 84.00 \mathrm{mg} / \mathrm{m}^{3} \mathrm{CO}, 798.67 \mathrm{mg} / \mathrm{m}^{3} \mathrm{NO}_{\mathrm{x}}$ for $30 \mathrm{ml}, 65.48 \mathrm{mg} / \mathrm{m}^{3} \mathrm{HC}, 160.33$ $\mathrm{mg} / \mathrm{m}^{3} \mathrm{CO}, 850.33 \mathrm{mg} / \mathrm{m}^{3} \mathrm{NO}_{\mathrm{x}}$ for $40 \mathrm{ml}, 87.31 \mathrm{mg} / \mathrm{m}^{3} \mathrm{HC}, 212.67 \mathrm{mg} / \mathrm{m}^{3} \mathrm{CO}, 801.33 \mathrm{mg} / \mathrm{m}^{3} \mathrm{NO}, 3.67 \mathrm{mg} / \mathrm{m}^{3}$ $\mathrm{SO}_{2}$ for $50 \mathrm{ml}$. This study shows that $\mathrm{CO}$ and $\mathrm{HC}$ exceeded the permissible limit for stationary sources while $\mathrm{NO}_{\mathrm{x}}$ and $\mathrm{SO}_{2}$ were below the permissible limit.

Conclusions: Hence, there is a need for rapid response and urgent attention from government and regulatory bodies to develop and implement appropriate policies that will help in reducing the effect. Appropriate measures to control air emissions that may be embarked upon by regulatory bodies include increase in the use of low-emission fuels and renewable fuels such as bio-fuels and introduction of the use of devices with low CO emissions.

Keywords : Combustion, Analyzer, Stationary Source, Pollutants, Premium Motor Spirit

\footnotetext{
Corresponding author

E-mail: okemicheal@gmail.com

Tel: 08130051265

(c) 2021, Korean Society of Environmental Engineers
}

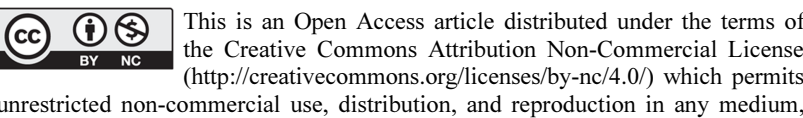
provided the original work is properly cited. 


\section{Introduction}

Crude is oil and other natural substances in their natural state before being treated with chemicals. Catalytic cracking and fractional distillation are the basic processes being employed in the refining of crude oil into petroleum products. These products possess both physical and chemical properties varying with the type of crude oil and refining processes. These extracts include Liquefied Petroleum Gas (LPG), Premium Motor Spirit (PMS), Dual Purpose Kerosene (DPK), Automotive Gas Oil (AGO), amongst other products. ${ }^{1)}$ Presently, Nigeria is ranked among the top ten world's largest producer and exporter of crude oil. ${ }^{2)}$ Petroleum products in the country include transportation fuels, cooking fuels for domestic use, fuel oils for heating processes and electricity generation, road constructions, raw materials for the production of chemicals and synthetic materials found in virtually everything we make use of. These refined products are combusted in engines like generators, vehicles, and many more, and the emission from these engines can cause air pollution. Combustion processes of these refined petroleum products possess characteristics that lead to the certain emission of gaseous and particulate pollutants in the atmosphere that have both primary and secondary impacts on ambient air quality. ${ }^{3)}$ Opined that the criteria air emissions from these combustion processes include carbon monoxide $(\mathrm{CO})$, oxides of nitrogen $\left(\mathrm{NO}_{\mathrm{x}}\right)$, particulate matter less than 10.0 microns in diameter $\left(\mathrm{PM}_{10}\right)$, Sulphur dioxide $\left(\mathrm{SO}_{2}\right)$, volatile organic compounds (VOCs) and water vapor $\left(\mathrm{H}_{2} \mathrm{O}\right)$ also with aerosol emissions that have severe influence on air quality, health, environment, and structures.

Prior to the discovery of crude oil in Oloibiri, Rivers State in 1956, agriculture was the driving force for the Nigerian economy. A high number of cities and towns in the country would have been considered environmentally friendly due to minimum industrial activities. The oil boom witnessed in the country during this period led to a monumental increase in industrialization which made the environment unfriendly to humans, structures, wildlife and aquatic bodies as regards air pollution. ${ }^{4,5)}$ Highlighted that due to the developing international demand around the world, most of the oil facilities in the country were developed between the 1960s and 1980s. The downstream sector of the petroleum industry in Nigeria is well established and organized. NNPC has four refineries, two in Port Harcourt as Port Harcourt Refining Company (PHRC), and one each in Kaduna as Kaduna
Refining and Petrochemical Company (KRPC) and Warri as Warri Refining and Petrochemical Company (WRPC). The refineries have a combined installed capacity of 445,000 barrels per day (bbl/day) where the combined installed capacity of PHRC is 210,000 barrels per day (bbl/day) and the installed capacity of both KRPC and WRPC are 110,000 barrels per day (bbl/day) and 125,000 barrels per day (bbl/day). A comprehensive network of pipelines and depots strategically located throughout the country links these refineries for the delivery of refined product. ${ }^{6}$

The industrial and commercial use of refined petroleum products has brought about immense growth and development in the country. The process of technology in the advancement of industrialization often resulted in unacceptable levels of toxic and effluent emissions. These culminated in air pollutant emissions and the degradation of the atmosphere and environment in general. Many environmental laws have been enacted with the aim of changing the makeup of refined petroleum effluents so that they can produce fewer and environmentally friendly emissions ${ }^{7)}$ but there are limited scientific efforts to establish if these laws are complied with. The objective of this paper is to examine the pollutants in the area to know if they are hazardous to the residents and to inform the government and regulatory bodies to take the appropriate steps.

\section{Materials and methods}

The materials and equipment used during the combustion of KRPC refined petroleum products include fuel samples gasoline, kerosene and diesel; measuring cylinder; a conical flask; a combustion chamber; an air compressor; a combustion analyzer.

\subsection{Study area - Kaduna Refining}

Kaduna Refining is located in the northern part of Nigeria, km 16 Kadhia road, (Chikun local government Kaduna, Nigeria) on latitude $10.411259^{\circ}$ and longitude $7.49065^{\circ}$ (Fig. 1). It has the capacity of producing 110,000 barrels per day. ${ }^{8)}$

\subsection{Combustion apparatus, fuel, and experimental procedure}

The E8500 plus combustion analyzer was used for gaseous emission characterization. It is the most powerful and advanced portable emissions analyzer on the market and is a complete, portable tool for EPA compliance-level emissions 


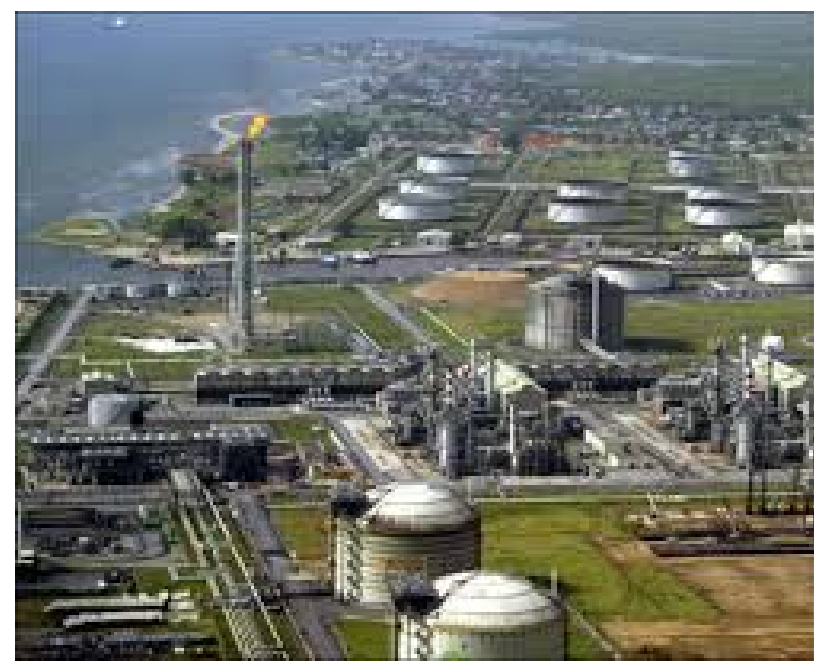

Fig. 1. Kaduna Refining and Petrochemical Company.

monitoring of boilers, engines, and other combustion equipment. It has up to nine gas sensors with a weight of 5 $\mathrm{kg}$ and a dimension of $26 \times 15 \times 24 \mathrm{~cm}$.

It is an analyzer equipped with an inbuilt thermoelectric chiller that efficiently and quickly removes water vapor from gas samples to prevent gases from bubbling into the condensate drain gas velocity measurement capability which makes the instrument scientifically efficient. Gaseous emissions from the combustion of refined petroleum products were measured using the E8500 plus portable industrial gas and emissions analyzer (Fig. 2). The combustion analyzer is capable of measuring gaseous emissions including; Oxygen $\left(\mathrm{O}_{2}\right)$, Hydrocarbons $(\mathrm{HC})$, carbon monoxide $(\mathrm{CO})$, carbon dioxide $\left(\mathrm{CO}_{2}\right)$, Oxides of Nitrogen $\mathrm{NO}_{\mathrm{x}}\left(\mathrm{NO}, \mathrm{NO}_{2}\right)$, Sulphur dioxide $\left(\mathrm{SO}_{2}\right)$, and Hydrogen Sulfide $\left(\mathrm{H}_{2} \mathrm{~S}\right)$. Its $\mathrm{CO}$ detection range is $0.0000-2,000.0000 \mathrm{ppm}$ with $1 \mathrm{ppm}$ resolution while its $\mathrm{NO}$ and $\mathrm{NO}_{2}$ detection range is $0.0000-400.0000 \mathrm{ppm}$ with $1 \mathrm{ppm}$ resolution. The detection range of its $\mathrm{H}_{2} \mathrm{~S}$ is $0.0000-500.0000 \mathrm{ppm}$ with $1 \mathrm{ppm}$ resolution. In addition, the temperature of the flue gas and the ambient air in its area of operation can also be measured with the analyzer at the range of $0-1,000^{\circ} \mathrm{C}$. It also measures pressure/draft excess air of combustion, gas velocity, and the efficiency of combustion.

The air compressor used is a 50-liter air receiver which has a $3 \mathrm{HP}, 230 \mathrm{~V}, 1 \mathrm{HP}$ motor with electrical overload protection. This $66 \mathrm{~kg}$ robust air compressor of $930 \times 420 \times 800 \mathrm{~mm}$ dimensions features a heavy-duty cast iron pump, designed to appeal to commercial, agricultural, and consumer users. It delivers a more-than-adequate volume \& pressure of compressed air. It has also a maximum working pressure of

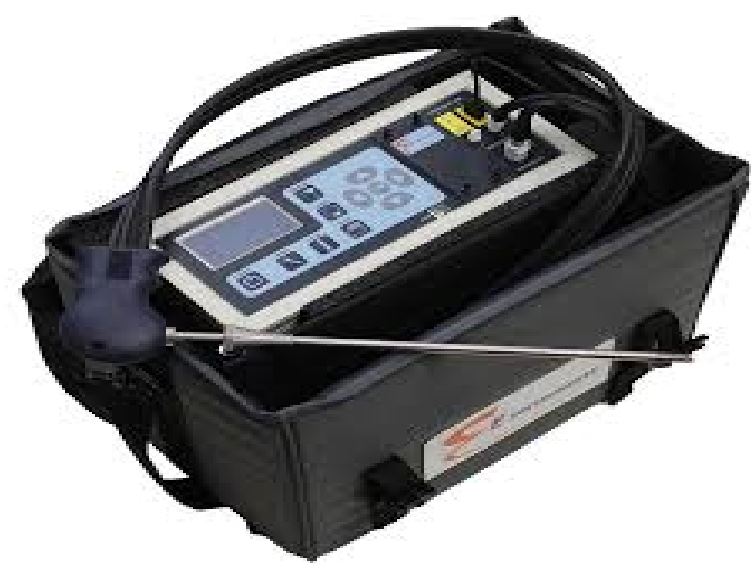

Fig. 2. E8500 Combustion gas analyser.

10.3000 bar (148.5000 psi) controlled by a fully automatic pressure switch. It has a cast-iron ' $\mathrm{V}$ ' type twin cylinder air compressor pump with $15 \mathrm{cfm}$ displacement. The air compressor is powered by a petrol-fueled engine that is placed far away from the combustion chamber and analyzer so that it does not influence the emissions being read by the analyzer. It is capable of providing a more than adequate volume and pressure of compressed air to power professional spray-guns and many of the frequently used air tools.

Without the gas sampling probe connected to the instrument, the combustion analyzer is turned on. Baseline calibration is required to zero out any sensors that may have drifted far from zero. After the required baseline calibration and there were no errors, the gas sampling probe is connected to the instrument. The electronic analyzer is now ready for use to monitor any gaseous emission for which the appropriate sensor is installed. Gaseous emissions including; Hydrocarbons (HC), carbon monoxide $(\mathrm{CO})$, carbon dioxide $\left(\mathrm{CO}_{2}\right)$, Oxides of Nitrogen $\left(\mathrm{NO}, \mathrm{NO}_{2}, \mathrm{NO}_{\mathrm{x}}\right)$, Sulphur dioxide $\left(\mathrm{SO}_{2}\right)$, and Hydrogen Sulfide $\left(\mathrm{H}_{2} \mathrm{~S}\right)$ were measured with the use of the combustion analyzer. All emissions were measured in $\mathrm{mg} / \mathrm{m}^{3}$ with the exception of $\mathrm{HC}$ and $\mathrm{CO}$ which was measured in ppm and \% respectively.

Fuel samples were stored in air-tight plastic containers to avoid contamination and maintain sample quality. The fuel containers were leak-proof to prevent the escape of gases including hydrocarbon. The volume of refined products was varied between $10 \mathrm{ml}$ and $50 \mathrm{ml}$. This was done to determine the time taken for each volume to be combusted and the characterization of the air pollutants. Also, to determine the emission rate of the gaseous pollutant which is the unit mass of gaseous emissions per time taken for characterization of the air pollutants from the combustion of PMS. For each 


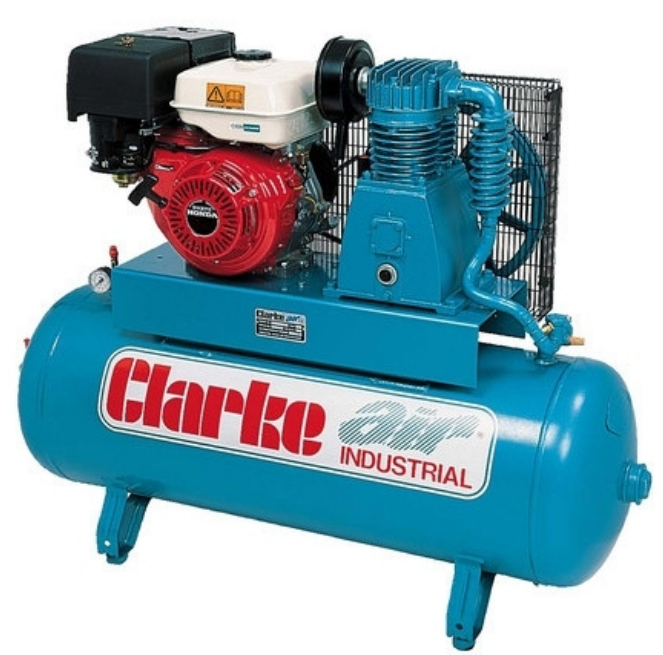

Fig. 3. Clarke air CE compressor.

experimental run, a varied volume of refined products was measured with a measuring cylinder.

\subsection{Sampling and measurement techniques}

Air was passed into the combustion chamber with the aid of a Clarke air CE compressor (Fig.3) to provide sufficient air for the combustion process. The air supplied was at a constant flowrate which was achieved at the maximum working pressure condition of the compressor, 10.3000 bar (148.5000 psi). The air compressor was powered by a petrol-fueled engine which was placed far away from the combustion chamber and analyzer so that the compressor emissions do not interfere with the emissions being read by the analyzer. The experimental setup is shown in Fig. 4.

For each experimental run, the measured volume sample of each PMS was transferred into the combustion chamber, air from the compressor was passed into the chamber and ignition was done via the ignition hole using a lightning gun. The lid was placed firmly on it as combustion commences. During the combustion process, gaseous emissions including; Hydrocarbons (HC), carbon monoxide (CO), carbon dioxide $\left(\mathrm{CO}_{2}\right)$, Oxides of Nitrogen $\left(\mathrm{NO}, \mathrm{NO}_{2}, \mathrm{NO}_{\mathrm{x}}\right)$, Sulphur dioxide $\left(\mathrm{SO}_{2}\right)$, and Hydrogen Sulfide $\left(\mathrm{H}_{2} \mathrm{~S}\right)$ were emitted into the atmosphere from the combustion chamber stack and into the atmosphere. The combustion analyzer gas probe was inserted into the combustion zone through the stack of the chamber in order to measure the accurate air pollutants coming directly from the combustion zone in the chamber as opposed to the ambient zone when measured from the top of the combustion chamber.

Readings were taken and recorded with the use of the

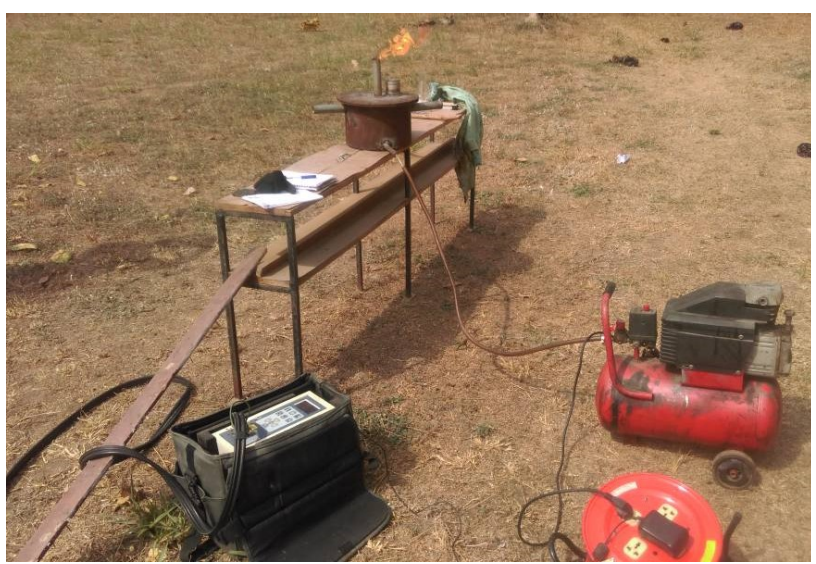

Fig. 4. Experimental setup.

combustion analyzer as the concentration values of air pollutants changed during the period of combustion. At the end of combustion, the combustion analyzer was calibrated back to zero in order to zero out the sensors that may have drifted far from zero. Three experimental runs were carried out for each volume of refined products that were varied.

\section{Results and discussion}

For the varied volume of PMS experiments carried out in the laboratory, the average measured gaseous emissions during the combustion of PMS are presented below. The statistical descriptions of the emissions from the PMS combustion can be seen in Fig. 5.

The measured average concentrations for the combustion of $10 \mathrm{ml}$ of PMS were $69.8446 \mathrm{mg} / \mathrm{m}^{3}$ of $\mathrm{HC}, 117.3333 \mathrm{mg} / \mathrm{m}^{3}$ of $\mathrm{CO}, 334.0000 \mathrm{mg} / \mathrm{m}^{3}$ of $\mathrm{NO}_{\mathrm{x}}$ and zero values were recorded for $\mathrm{CO}_{2}$ and $\mathrm{SO}_{2}$. For $20 \mathrm{ml}$ of PMS, the measured average concentrations were $58.9322 \mathrm{mg} / \mathrm{m}^{3}$ of $\mathrm{HC}, 130.3333 \mathrm{mg} / \mathrm{m}^{3}$ of $\mathrm{CO}, 784.3333 \mathrm{mg} / \mathrm{m}^{3}$ of $\mathrm{NO}_{\mathrm{x}}$ and zero values were recorded for $\mathrm{CO}_{2}$ and $\mathrm{SO}_{2}$. For $30 \mathrm{ml}$ of PMS, the measured average concentrations were $50.2010 \mathrm{mg} / \mathrm{m}^{3}$ of $\mathrm{HC}, 84.0000 \mathrm{mg} / \mathrm{m}^{3}$ of $\mathrm{CO}, 798.6673 \mathrm{mg} / \mathrm{m}^{3}$ of $\mathrm{NO}_{\mathrm{x}}, 4.0000 \mathrm{mg} / \mathrm{m}^{3}$ of $\mathrm{SO}_{2}$ and zero values were recorded for $\mathrm{CO}_{2}$.

For $40 \mathrm{ml}$ of PMS, the measured average concentrations were $65.4800 \mathrm{mg} / \mathrm{m}^{3}$ of $\mathrm{HC}, 160.3333 \mathrm{mg} / \mathrm{m}^{3}$ of $\mathrm{CO}, 850.3333$ $\mathrm{mg} / \mathrm{m}^{3}$ of $\mathrm{NO}_{\mathrm{x}}, 3.0000 \mathrm{mg} / \mathrm{m}^{3}$ of $\mathrm{SO}_{2}$ and $3000.0000 \mathrm{mg} / \mathrm{m}^{3}$ of $\mathrm{CO}_{2}$. For $50 \mathrm{ml}$ of $\mathrm{PMS}$, the measured average concentrations were $87.3074 \mathrm{mg} / \mathrm{m}^{3}$ of $\mathrm{HC}, 212.6668 \mathrm{mg} / \mathrm{m}^{3}$ of $\mathrm{CO}, 801.3333 \mathrm{mg} / \mathrm{m}^{3}$ of $\mathrm{NO}_{\mathrm{x}}, 3.6667 \mathrm{mg} / \mathrm{m}^{3}$ of $\mathrm{SO}_{2}$ and $6,600.0000 \mathrm{mg} / \mathrm{m}^{3}$ of $\mathrm{CO}_{2}$.

The measured concentration of gaseous pollutants for $10 \mathrm{ml}$ of PMS for the three (3) experimental runs were in the range 


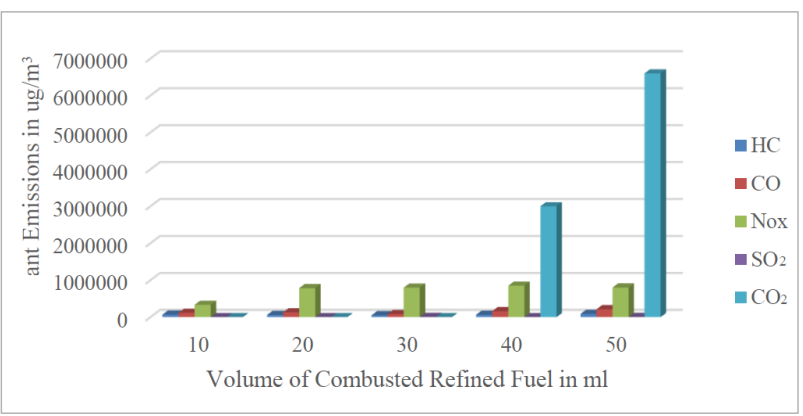

Fig. 5. Descriptive statistic of gaseous emissions from the combustion of varying volumes of PMS.

of $65.4800-72.0280 \mathrm{mg} / \mathrm{m}^{3}$ for $\mathrm{HC}, 17.0000-152.0000$ $\mathrm{mg} / \mathrm{m}^{3}$ for $\mathrm{CO}, 286.0000-472.0000 \mathrm{mg} / \mathrm{m}^{3}$ for $\mathrm{NO}_{\mathrm{x}}, 0.0000$ $\mathrm{mg} / \mathrm{m}^{3}$ for $\mathrm{SO}_{2}$ and $0.0000 \mathrm{mg} / \mathrm{m}^{3}$ for $\mathrm{CO}_{2}$, the mean and standard deviation were $69.8450 \pm 3.0872,117.3333 \pm 72.0663$, $334.0000 \pm 99.1030$ for $\mathrm{HC}, \mathrm{CO}$ and $\mathrm{NO}_{\mathrm{x}}$ respectively.

The measured concentration of gaseous pollutants for $20 \mathrm{ml}$ of PMS for the three (3) experimental runs were in the range of $58.9322-65.7800 \mathrm{mg} / \mathrm{m}^{3}$ for $\mathrm{HC}, 132.0000-138.0000$ $\mathrm{mg} / \mathrm{m}^{3}$ for $\mathrm{CO}, 773.0000-798.0000 \mathrm{mg} / \mathrm{m}^{3}$ for $\mathrm{NO}_{\mathrm{x}}, 0.0000$ $\mathrm{mg} / \mathrm{m}^{3}$ for $\mathrm{SO}_{2}$ and $0.0000 \mathrm{mg} / \mathrm{m}^{3}$ for $\mathrm{CO}_{2}$, the mean and standard deviation were $58.9320 \pm 5.3500,130.3333 \pm 7.0000$, $784.3333 \pm 8.0000$ for $\mathrm{HC}, \mathrm{CO}$ and $\mathrm{NO}_{\mathrm{x}}$ respectively.

The measured concentration of gaseous pollutants for $30 \mathrm{ml}$ of PMS for the three (3) experimental runs were in the range of $39.2883-52.3842 \mathrm{mg} / \mathrm{m}^{3}$ for $\mathrm{HC}, 59.0000-132.0000$ $\mathrm{mg} / \mathrm{m}^{3}$ for $\mathrm{CO}, 645.0000-834.0000 \mathrm{mg} / \mathrm{m}^{3}$ for $\mathrm{NO}_{\mathrm{x}}, 3.0000$ $-5.0000 \mathrm{mg} / \mathrm{m}^{3}$ for $\mathrm{SO}_{2}$ and $0.0000 \mathrm{mg} / \mathrm{m}^{3}$ for $\mathrm{CO}_{2}$, the mean and standard deviation were $50.2011 \pm 8.1722,84.0000 \pm$ $34.0000,798.6672 \pm 113.1000,4.0000 \pm 0.8200$ for $\mathrm{HC}, \mathrm{CO}$, $\mathrm{NO}_{\mathrm{x}}$ and $\mathrm{SO}_{2}$ respectively.

The measured concentration of gaseous pollutants for $40 \mathrm{ml}$ of PMS for the three (3) experimental runs were in the range of $65.7800-72.0282 \mathrm{mg} / \mathrm{m}^{3}$ for $\mathrm{HC}, 34.0000-221.0000$ $\mathrm{mg} / \mathrm{m}^{3}$ for $\mathrm{CO}, 805.0000-970.0000 \mathrm{mg} / \mathrm{m}^{3}$ for $\mathrm{NO}_{\mathrm{x}}, 3.0000$ $-3.0000 \mathrm{mg} / \mathrm{m}^{3}$ for $\mathrm{SO}_{2}$ and $0.0000-5,400.0000 \mathrm{mg} / \mathrm{m}^{3}$ for $\mathrm{CO}_{2}$, the mean and standard deviation were $65.4800 \pm 5.3462$, $160.3333 \pm 89.4000,850.3333 \pm 85.4000,3.0000 \pm 0.0000$, $3000.0000 \pm 224.4000$ for $\mathrm{HC}, \mathrm{CO}, \mathrm{NO}_{\mathrm{x}}, \mathrm{SO}_{2}$ and $\mathrm{CO}_{2}$ respectively.

The measured concentration of gaseous pollutants for $50 \mathrm{ml}$ of PMS for the three (3) experimental runs were in the range of $72.0282-91.6732 \mathrm{mg} / \mathrm{m}^{3}$ for $\mathrm{HC}, 146.0000-264.0000$ $\mathrm{mg} / \mathrm{m}^{3}$ for $\mathrm{CO}, 767.0000-864.0000 \mathrm{mg} / \mathrm{m}^{3}$ for $\mathrm{NO}_{\mathrm{x}}, 3.0000$ $-4.0000 \mathrm{mg} / \mathrm{m}^{3}$ for $\mathrm{SO}_{2}$ and $5,400.0000-7,200.0000 \mathrm{mg} / \mathrm{m}^{3}$ for $\mathrm{CO}_{2}$, the mean and standard deviation were $87.3070 \pm$
Table 1. Emission limits for specific pollutants from stationary source. ${ }^{9)}$

\begin{tabular}{cc} 
Pollutant & Limits $\left(\mathrm{mg} / \mathrm{m}^{3}\right)$ \\
Carbon monoxide & 10 \\
Hydrocarbon & 50 \\
Oxides of nitrogen & $350-1,000$ \\
Sulphur dioxide & $30-3,000$ \\
\hline
\end{tabular}

$11.1293,212.6667 \pm 49.4000,801.3333 \pm 44.4000,3.6667 \pm$ $0.4700,6600.0000 \pm 848.5000$ for $\mathrm{HC}, \mathrm{CO}, \mathrm{NO}_{\mathrm{x}}, \mathrm{SO}_{2}$ and $\mathrm{CO}_{2}$ respectively.

When the emissions of PMS combustion from varying volume $(10 \mathrm{ml}-50 \mathrm{ml})$ are compared with $\left.{ }^{9}\right)$ limits for gaseous emissions from stationary sources in Table 1, $\mathrm{HC}$ and $\mathrm{CO}$ emitted from PMS combustion breached the permitted emission limit for stationary sources. For $\mathrm{NO}_{\mathrm{x}}\left(\mathrm{NO}\right.$ and $\left.\mathrm{NO}_{2}\right)$, it was observed that its emission from PMS combustion was below the permitted limits for stationary sources. Also, it was observed that the emissions of $\mathrm{SO}_{2}$ were below both the lower and the upper set limits. Deduced from the comparison, emissions from PMS combustion were below the set standards permitted for stationary sources except for carbon monoxide and hydrocarbon emissions. Hence PMS from KRPC could serve as a source of energy with sustainable environmental effects.

\section{Conclusions}

This study identifies air pollutants associated with the combustion of PMS. Premium Motor Spirits (PMS) was combusted in an experimental chamber. Air pollutants such as Hydrocarbons (HCs), Carbon Monoxide (CO), oxides of Nitrogen (NOx), Sulphur dioxide $\left(\mathrm{SO}_{2}\right)$ and Carbon dioxide $\left(\mathrm{CO}_{2}\right)$ were characterized with the use of a combustion gas analyzer and these pollutants when released into the environment, consistently and significantly affects the air quality of the study area.

The gaseous emissions of $\mathrm{CO}$ and $\mathrm{HC}$ exceeded the set standards while that of $\mathrm{NO}_{\mathrm{x}}$ and $\mathrm{SO}_{2}$ are below the permissible limit. It can be inferred that most of the criteria air pollutants emitted from the sources considered in this study presently have concentrations that are above the ambient air quality standards. However, the cumulative effects of these air emissions continue to result in the poor air quality of the study area which poses a great health risk for the citizens. Although the current level of air quality is not totally hidden to the 
government and environmental protection agencies in the state, efforts are being made to reduce the emission into the atmosphere of these pollutants by planting trees, introducing controlled packing zones, establishment of carbon registry, but much more is needed to be done because there is no doubt that this scenario has continued to lead to environmental hazards, loss, and damage of lives and properties.

Therefore, there is a need for rapid response and urgent attention from regulatory bodies to develop and implement appropriate policies that will help in managing the air quality effectively. Appropriate measures to control air emissions that may be embarked upon by regulatory bodies include increase in the use of low-emission fuels and renewable fuels such as bio-fuels and introduction of the use of devices with low $\mathrm{CO}$ emissions. This data could also be used to determine the cumulative effects of these air emissions continue to result into the poor air quality of the study area which poses a great health risk for the citizens (using the emission factor ${ }^{10)}$ ).

\section{References}

1. R. M. Harrison, Pollution: cause effects and control: based on the papers given at a residential school, Continuing Education Committee of the Royal Society of Chemistry, London, UK, pp. 1-322(1982).

2. I. M. Sani, The Implications of price changes on petroleum products distribution in Gwagwalada Abuja, Nigeria, J. Energy Techn. Policy, 4(7), 1-7(2014).

3. J. S. Gaffney, N. A. Marley, The impacts of combustion emissions on air quality and climate-from coal to biofuels and beyond, Atmos. Environ., 43(1), 23-36(2009).

4. L. C. Osuji, G. O. Avwiri, Flared gases and other pollutants associated with air quality in industrial areas of Nigeria: an overview, Chem. Biodiv., 2(10), 1277-1289(2005).

5. R. M. Rotty, First estimates of global flaring of natural gas, Atmos. Environ., 8(7), 681-686(1974).

6. Nigerian National Petroleum Corporation, http://nnpcgroup. com/NNPCBusiness/MidstreamVentures/RefineriesPetrochemi cals.aspx, August(2017).

7. USDOE Office of Fossil Energy, Environmental benefits of advanced oil and gas exploration and production technology, USDOE Office of Fossil Energy, Washington, D.C., USA, pp. 1-168(1999).

8. T. Oladimeji, J. Sonibare, M. Odunfa, A. Ayeni, Modeling of criteria air pollutant emissions from selected Nigeria petroleum refineries, J. Power Energy Eng., 3(6), 31-45(2015).
9. Federal Environmental Protection Agency, Guidelines and standards for environmental, pollution control in Nigeria, Federal Environmental Protection Agency, Washington, D.C., USA, pp. 1-238(1991).

10. O. M. Abidemi, O. O. Adedayo, S. A. Jacob, A. F. Alaba, Estimation of emission factor from the combustion of AGO, PMS and DPK from the Kaduna Refinery and Petoleum Company in Nigeria, Int. J. Technol. Res. Eng., 8(4), 25-29(2020).

\section{Declaration of Competing Interest}

The authors declare that they have no known competing financial interests or personal relationships that could have appeared to influence the work reported in this paper.

\section{Authors and Contribution Statement}

\section{Osunnusi Oluwaseun Adedayo}

Department of Chemical Engineering, Obafemi Awolowo University, M. Sc, ORCID (0) 0000-0002-6338-5353: Data analysis, Methodology.

\section{Oke Michael Abidemi}

Department of Chemical Engineering, Obafemi Awolowo University, Ph. D. Student, ORCID (이 0000-0001-6773-3186: Writing - review and editing.

\section{Odekanle Ebenezer Leke}

Department of Chemical Engineering, Technical University, Ph. D. Student, ORCID (D) 0000-0002-1260-0383: Validation.

\section{Sonibare Jacob Ademola}

Department of Chemical Engineering, Obafemi Awolowo University, Ph. D. Student, ORCID (D) 0000-0002-1121-5977: Supervision.

\section{Ige Oluwafunmiso Ayodele}

Department of Chemical Engineering, Obafemi Awolowo University, M. Sc: Project administration.

\section{Oyewale Babatunde Oyeleke}

Department of Chemical Engineering, Obafemi Awolowo University, Ph. D. Student: Conceptualization.

\section{Odewale Stephen Ayodele}

Department of Chemical Engineering, Obafemi Awolowo University, Ph. D. Student: Data curation, Resources. 